\section{Entre sinos e atabaques}

\section{Elcio Cornelsen}

A revista FuLiA / UFMG apresenta o belo conto em que o autor "se debruça sobre as relações entre o futebol e a religião, tomando como fio condutor as experiências de um garoto no dia da lendária final do Campeonato Paulista de 1977, quando o Corinthians sagrou-se campeão após um jejum de mais de 22 anos".

Elcio Cornelsen é professor Associado III da Faculdade de Letras da UFMG. Publicou o poema "Inusitado" na antologia Pelada poética (Scriptum, 2014), a série poética "Ludopoesias", na revista Em Tese (2014), e o poema "Escalação" na antologia do Prêmio UFF de Literatura, Editora da UFF, 2014.
Edson nem sabia direito o que significava a palavra exorcismo. Sem saber, era o que fazia naquela tarde. Riscava a giz, com certa precisão, o símbolo da Ponte Preta no piso de cimento do quintal de sua casa. Nem imaginava que o espectro da Macaca, personagem de um romance publicado um ano depois, de um de seus mais ilustres torcedores, poderia estar rondando os ares da periferia da megalópole.

O sofrimento do alvinegro era épico, doído, remoído por décadas de decepção, desde o título do 4o Centenário, em 1954, como se anunciasse, feito agouro, que o time ficaria mais quatrocentos anos para vencer algum torneio. E Edson sabia disso. Tinha sofrido no último domingo a decepção de ver seu time derrotado em pleno Morumbi lotado pelo placar de 2 a 1 .

Sem saber, procurava exorcizar o adversário, prendêlo em seu desenho de giz, ou será que idolatrava o adversário e reconhecia que, mais uma vez, o alvinegro sucumbiria, desta vez, para outro alvinegro que buscava um lugar ao sol? Não fazia muito tempo, morava vizinho de um terreiro de Umbanda, e não muito longe de sua casa, ficava a paróquia do bairro, cujo telhado dominava a paisagem lá no alto. Suas mais tenras 
memórias foram se construindo ao som de sinos e do altofalante anunciando a oração da Ave Maria às 18h00, e também ao som dos atabaques, das cantigas aos Orixás e dos gritos de transe e incorporação durante os rituais.

Edson acreditava poder interferir no destino. Desenhara a silhueta do símbolo, a sigla A. A. P. P., Associação Atlética Ponte Preta, bem grande. Desde domingo, a Ponte povoava seus pensamentos, mais que seu próprio clube de coração. Amava o alvinegro, amava o desempenho limitado daqueles dias, porém, de extrema dedicação de seus jogadores. Mas respeitava o adversário. Na escola, na rua ou em casa, um só pensamento, o destino.

A ansiedade era tanta que os ponteiros do relógio pareciam se arrastar naquele final de tarde. Ave Maria cheia de graça, o Senhor é convosco, bendita sois Vós entre as mulheres, $e$ bendito é o fruto do vosso ventre, Jesus. Acendeu a luz do quintal para mirar mais uma vez o desenho no chão, bem delineado em giz branco, com traços fortes. Santa Maria, Mãe de Deus, rogai por nós pecadores, agora e na hora da nossa morte. Amém.
Voltou para a sala junto de seu tio, que o havia iniciado na devoção pelo alvinegro, e junto de sua irmã. Diante do antigo televisor a válvulas, os três aguardavam com ansiedade o início da partida. Edson não falou nada do símbolo riscado a giz. Já podia se ouvir a cadência dos atabaques. Ah, como é lindo o batuque do Tambor. Ah, como é lindo o batuque do Tambor. Piiiiióóóóóóóóóóóóóó!!!!! Os times entram em campo. Quem canta, encanta a vida dos Orixás. Estão completos. É uma benção divina que emana muita paz. 0 símbolo riscado a giz no chão. Serão mais 90 minutos de tensão e apreensão, como no último domingo e na quarta-feira da semana passada, rogai por nós pecadores. Os primeiros 45 minutos se consomem em lances agudos de ambas as partes, mas nada de gol. É a oração que elevo ao senhor. É a vibração que nos faz incorporar. Intervalo, agora e na hora da nossa morte.

0 trio de arbitragem já se posta, preparado para decretar o começo da segunda etapa, aqueles quarenta e cinco minutos finais que poderão significar a sagração ou o luto eterno. Será que a força do desenho a giz se manifestará? Os atabaques silen- 
ciaram. Ah, como é lindo o batuque do Tambor. Os sinos também não anunciam o desfecho, bendito é o fruto do vosso ventre.

10 segundos, esse momento fugaz, 10 segundos, registraria o fato que se tornaria mito. Num dia 13, e nem era sexta-feira, aqueles 10 segundos, o Senhor é convosco, Ah, como é lindo, fariam Edson vivenciar a pura epifania. Piiiiióóóóóóóóóóóóóó!!!!! 36 minutos e 38 segundos: da direita, bola na área, chute, trave, de cabeça, zagueiro salva, sobra bola. 36 minutos e 48 segundos: gol. Perna direita marca, perna de santo. 0 dragão está no chão, vazado pela lança. Na roda de dança, os atabaques. Eu não sabia, mas agora aprendi. Santa Maria, Mãe de Deus, o desenho a risco de giz. Ogum. Amém. 